\title{
1. European solidarity: an introduction to a multifaceted phenomenon
}

\section{Christian Lahusen}

\subsection{INTRODUCTION}

Solidarity has become a strongly debated issue within the European Union. Ongoing conflicts between member states about financial solidarity with states affected severely by the economic crisis of 2008 and about fair burden-sharing with regard to the high numbers of refugees show the difficulties of living up to the standard of solidarity which the EU lists in its treaties as one of its guiding principles. At the same time, the debate unveils that solidarity is highly contested. The reservations of EU member states to share the burdens regarding the costs of the economic crisis and the migration inflow can be criticised as a lack of interstate solidarity and a prioritisation of national interests; they also evidence a more fundamental difficulty in agreeing on adequate public policies and coordinated problem-solving strategies. Governments are sensitive to nationalist and populist mobilisations and parties, whose electoral successes seem to limit the readiness of member states to engage beyond what might be conceived of as an instrumental and utilitarian solidarity of 'quid pro quo'. More than that, nationalist and populist parties contest the idea of European solidarity precisely in the name of national solidarity, and the need to defend national communities against outside interventions.

Hence, controversies about solidarity prevail within the public sphere. These debates, however, have paid more attention to interstate solidarity, thus marginalising another topic that is much less discussed and researched: European social or civic solidarity. In fact, even though we might expect that both dimensions are interrelated, it is necessary to differentiate between solidarity among states and solidarity between European citizens, between the 'intergovernmental' and 'transnational' dimensions of solidarity, and between the 'vertical' support of interstate solidarity by citizens and the 'horizontal' engagement of citizens in cross-border relations of support and help (Apostoli, 2012: 4). Very little is known about the amount of transnational solidarity and the effects of 
the current crises on it. On the one hand, we might expect that 70 years of European integration should have helped to promote the idea of European solidarity between citizens. The European integration process has gradually established feelings of belongingness to the European community, promoting shared identifications with Europe and the EU (Delanty and Rumford, 2005; Beck and Grande, 2007; Fligstein, 2008). Moreover, European integration has furthered cross-national experiences and contact among citizens, as well as transnational trust between European people (Delhey, 2007). Finally, public opinion polls show that in the midst of the European crisis, a slim majority of respondents agreed that it is desirable to give financial help to other countries in times of crisis (i.e., $50 \%$ against $44 \%$ ), and this support increases slightly (55\%) when addressed in terms of inner-European solidarity (Raspotnik et al., 2012). Recent survey data from 13 member states even show that the support for redistributive policies is rather widely diffused within the European Union, given that more than $60 \%$ of respondents agreed in 2016 that financial help should be given to other EU countries facing severe economic difficulties (Gerhards et al., 2018). All this shows that Europeans approve of the idea of solidarity and redistribution also within the EU (Börner, 2014; Gerhards et al., 2019).

On the other hand, it is also true that the intensity and the number of crises lived out within the EU seems to impact on rates of European solidarity, both between governments and citizens. Populist and Eurosceptic parties are mobilising a wider group of voters (Krouwel and Abts, 2007; Hutter and Grande, 2014; Kriesi and Pappas, 2015), and this means that not all EU governments can be relied on to stand by the majority in favour of EU membership. The 'Brexit' vote in June 2016 shows how fragile these majorities can be. Since then, the choice of opting out is on the table and is being discussed in a number of other member states. Beyond the erosion of enthusiasm for the European cause, we also know from research that European solidarity is also patterned with cleavages along North-South and West-East divides, between 'Europeans' and 'not-yet Europeans' (Eder, 2005), between countries with higher degrees of mutual trust (Northern and Western Europe) and the others (Delhey, 2007). Additionally, we need to take into consideration the fact that transnational solidarity between citizens does not seem to be diffused evenly among European people, but differentiated along socio-demographic traits, civic skills, political attitudes and cultural beliefs (see e.g., Kriesi et al., 2006; Lahusen and Grasso, 2018).

These observations show that European solidarity is badly equipped to arouse consensus. Not only are EU member states and governments in disagreement about interstate solidarity, but citizens are also divided when called to support other European countries and citizens. While agreement 
is more probable when European solidarity is addressed in general terms, dissent is more likely once we move to specific measures and policies of cooperation, burden-sharing and financial help. In fact, solidarity might be a highly cherished value, but once we consider solidarity in practice, various lines of contention emerge. Citizens might disagree about which particular group to prioritise, i.e., whether national, European or global solidarity should be the first choice. Additionally, citizens might have different views about whether solidarity should be granted unconditionally or should be constrained to specific groups along considerations of trustworthiness, reciprocity, neediness, social proximity or deservingness. Finally, dissent will emerge when asking citizens whether solidarity should be a matter of charitable help, informal exchange relations, political demands or binding legal entitlements. In all these aspects, we must expect that cross-border civic solidarity will most probably be a restrained, contested and potentially fragile phenomenon.

So far, scholarly writing has generated little evidence on the scope and structure of citizens' solidarity within Europe. Research has been interested in citizens' preferences for solidarity, but the focus was primarily on the 'vertical' support or institutionalised forms of solidarity, such as welfare institutions and social policies at the national and European level (Svallfors, 1997; Alesina and Giuliano, 2011; Baute et al., 2018; Gerhards et al., 2018, 2019). Less attention is paid to relations of solidarity between citizens across countries, hence, with the horizontal and/or transnational component of solidarity. This book aims to fill in part of this gap by presenting findings from an EU-funded project that has been devoted to the analysis of European solidarity. Its mission was to analyse the "European paths to transnational solidarity at times of crisis: Conditions, forms, role models and policy responses" (TransSOL). Research work was conducted between June 2015 and May 2018, with funding from the Horizon 2020 research programme (Grant Agreement No. 649435). Its main objectives were, among others, to assemble a systematic and cross-national database on solidarity in Europe at various levels of analysis (individual citizens, civil society, public policies and public discourses), to engage in an analysis of factors and forces promoting and inhibiting solidarity at these various levels, and to identify good practices and propose recommendations about remedial measures and policies. In all these aspects, we were geared to paint a nuanced and differentiated picture of European solidarity that does justice to its multifaceted and contentious nature. In fact, while it is important to map and measure the general readiness of Europeans to support others in need, we argue that it is also important to ask for the 'specific' readiness to help 'specific' groups of people, given that solidarity might be tied to various notions of conditionality. For this purpose, our analyses were 
comparative in two respects: we were interested in measuring and analysing solidarity with regard to various target groups (people with disabilities, the unemployed, migrants or refugees) and territorial entities (people living in their own countries, within the EU or outside). Additionally, research was conducted in eight countries in parallel (Denmark, France, Germany, Greece, Italy, Poland, Switzerland and the UK) in order to give an authentic picture of the diversity of situations within Europe and the diversity of contexts impinging on (European) solidarity.

Our research was devoted to a number of leading questions. How strong is solidarity among Europeans after almost 70 years of European integration? How is European solidarity organised in terms of civic groups and initiatives, organisational fields and transnational networks? How far is European solidarity also a contested issue within public debates, and does the public sphere contribute to the construction and/or erosion of the idea of European solidarity? And what do we know about beneficial and detrimental factors affecting European solidarity at the level of citizens, organisational fields and public spheres? In order to answer these overarching questions, we devoted our research to specific areas of inquiry. First, we were interested in measuring and studying attitudes and activities of solidarity at the level of individual citizens by means of a representative survey (see Chapter 2). Second, we mapped and analysed organised forms of civic solidarity within and across member states, by focusing on civil society initiatives, non-governmental organisations and/or protest groups at the grass-roots level (see Chapter 3 ) and at the national- and EU-levels (see Chapter 4). Third, we engaged in addressing solidarity at the societal level, as well. For this purpose, we analysed the role of solidarity within the legal framework and public policies of the eight countries and at EU-level (see Chapter 5), and we engaged in an analysis of public discourses within the print and social media in order to better understand how ideas and principles of (European) solidarity are constructed and eroded (see Chapters 6 and 7). Our aim was to gather systematic data and thus provide the empirical foundation for an in-depth description and analysis of European solidarity in its various components and contexts.

These empirical analyses were grounded in a project-internal, yearlong debate about conceptual and theoretical issues, because 'solidarity' is a widely used and multifaceted concept. Any attempt to unpack (European) solidarity in empirical terms will simply confirm that the object of this research is highly complex, broad and diffuse. The complexity and breadth of the phenomenon is even increased when consulting scholarly writing, given that solidarity has received a great deal of attention in the long history of the social sciences (Bayertz, 1999; de Deken et al., 2006; Stjernø, 2012; Smith and Sorrell, 2014). Various disciplines and research strands 
have been devoted to the analysis of solidarity, with very different research questions and aims in mind. Consequently, the study of solidarity is dominated by a diversity of disjointed inquiries and fragmented insights. Moreover, we lack a discussion about whether existing knowledge about solidarity is a fruitful reference point for the analysis of solidarity within the EU. The attempt of TransSOL has been to overcome this fragmented situation by developing a conceptually integrated, multidimensional research framework. In the following, we wish to present this analytical framework in more detail. In a first step, we will assemble available evidence, systematise empirical insights and discuss conceptualisations. In a second step, we will propose a consistent framework of analysis that promises to be well adapted to the study of European solidarity.

\subsection{EUROPEAN SOLIDARITY AS A RESEARCH FIELD: THE STATE OF THE ART}

Solidarity is a topic that has always played an important role in the social sciences, because it has been identified as a core element for the constitution of social order and societal cohesion (Alexander, 1980; Durkheim, 1997). As a consequence, social theory and empirical research has tended to develop very different insights into the core dimensions, causes and consequences of solidarity (Bayertz, 1999; Maull, 2009). The field of research is marked by divergent concepts and understandings (Giugni and Passy, 2001; Featherstone, 2012). This brief overview already points to an interesting paradox of previous research: There is an overabundance of concepts and assumptions, but little reflection on the multifaceted and contested nature of solidarity. At the same time, there is an overabundance of empirical evidence on various aspects, as will be shown, but little data on those aspects at the centre of our own analyses, namely transnational solidarity in the EU.

Before engaging in the development of a conceptual and theoretical framework of analysis, it thus seems necessary to map the immediately relevant fields of research. The latter can be grouped as follows: the study of European integration; the analysis of the public's support for re-distributional policies and institutions; studies on transnational (solidarity) movements and civil societies; and research about interpersonal or inter-organisational help between citizens. As we will explain later on, these areas conform to the three levels of aggregation of solidarity, the macro, meso and micro levels, to which TransSOL was devoted.

The first and largest strand of research focuses on societies, and thus on large-scale entities. One basic line of reasoning is devoted to 
a sociological analysis of modern societies, whose internal complexity leads to civic, voluntaristic and/or universalistic forms of solidarity (e.g., Parsons, 1951; Alexander, 1980; Durkheim, 1997). The construction of the European Communities fits into this argument, because European integration is perceived as a process that deepens the division of labour and the interconnectedness of people and corporate actors across borders (Münch, 2012). Increasing interdependencies and shared identities become an important precondition for a more stable European Union, growing solidarity between member states and citizens, and developing reciprocal obligations between them (Mau, 2006; Börner, 2013; Gerhards and Lengfeld, 2015). Recent debates tend to be more sceptical about the possibility of developing stable forms of transnational solidarity within the EU (e.g., Schäfer and Streeck, 2013), particularly because the economic and so-called refugee crisis seem to undermine the societal and institutional foundations of European solidarity (e.g., Galpin, 2012; della Porta and Mattoni, 2014). However, the normative strand of this debate still insists on the need to cultivate transnational and/or postnational forms of solidarity that are able to absorb the disintegrative effects of globalisation and Europeanisation. Most often, they point to the political and constitutional preconditions for the development of a transnational or universalistic solidarity (Brunkhorst, 1997, 2005; Habermas, 2013). In this regard, a democratically grounded, and transnationally knit European citizenship is highlighted as an important building block for a solidarity that transcends both national divisions and discriminations (e.g., Balibar, 2004: 44; 2014: 162-3; Jacobs, 2007; Dobson, 2012; Guild et al., 2013; Isin and Saward, 2013).

Next to these theoretical debates, empirical research in the social sciences has been guided by the attempt to identify measurable indicators of solidarity. In this area, we can identify a second field of research that is made up of empirical studies that inquire into re-distributional preferences, most often with a focus on social policies. These studies are relevant for our purposes, because they argue that welfare states and social policies are institutionalised forms of wealth redistribution and collective solidarity (Svallfors, 1997; Fong, 2001; Amat and Wibbels, 2009; Alesina and Giuliano, 2011; Rehm et al., 2012). Studying public support of redistributive policies is thus taken as a measure of vertical solidarity, and thus for the readiness of people to support institutionalised solidarity, i.e., to finance and endorse public programmes aimed at sharing wealth with the needy. This empirical focus has the advantage of measuring solidarity at the individual level indirectly: it allows us to understand the redistributive preferences and attitudes of people, their cognitive correlates, and social-structural determinants. Many of these studies are comparative 
(e.g., Blekesaune and Quadagno, 2003; Scheepers and Grotenhuis, 2005; Banting and Kymlicka, 2006; Brooks and Manza, 2007), and allow for an explanation of vertical solidarity with reference to individual factors (micro) and country-level determinants (macro). In this sense, they provide an important source of inspiration to identify explanatory factors impinging on individual solidarity.

A third research strand is located at the meso level of analysis, and deals with civil societies and social movements. The basic line of reasoning is that civil societies and social movements can be conceived as organisational fields of collective action that mobilise, organise and stabilise solidarity within and across countries. Social movements and civic groups do not only rally for solidarity with specific target groups, but also require internal solidarity among their supporters and members in order to arouse and sustain collective action. As we will see, these studies point to the importance of resources and collective identities (Hirsch, 1986; Polletta and Jasper, 2001; Hunt and Benford, 2004). This insight applies to the transnational level as well, because scholars have argued that the mobilisation of collective actions and social movements across borders depends on the ability to arouse identity and solidarity (e.g., Smith et al., 1997; Batliwala, 2002; Bandy and Smith, 2005; della Porta and Caiani, 2011; della Porta, 2018). Finally, studies in this field of research underscore solidarity as a contested field. Social movements that rally for solidarity with certain target groups are often confronted with counter-mobilisations and/or competing issues and missions (e.g., Kriesi and Pappas, 2015; della Porta, 2018). As a result, organised solidarity, out of necessity, builds on group identities that erect distinctions between 'us' and 'them', heightening antagonism between both. In-group solidarity might thus imply out-group enmity.

Finally, the analysis of horizontal solidarity can also benefit from the extensive field of studies on social capital at the micro level. Many of these studies are interested in forms of interpersonal help and support; they highlight the importance of (interpersonal and institutional) trust; and they emphasise the importance of membership and active participation in voluntary groups and civic associations (Bourdieu, 1986; Anheier and Salamon, 1999; Putnam et al., 2003; van Oorschot et al., 2006; Brown and Ferries, 2007; Bauer et al., 2013). Research tends to converge on the conviction that social capital is the necessary 'glue' of social cohesion (Jeannotte, 2000; Chan and Chan, 2006), and thus also essential for understanding the conditions, structures and dynamics of solidarity. In explanatory terms, scholars have tended to confirm the importance of socio-demographic determinants (e.g., social class, age, and gender), attitudes (post-materialist values and religious beliefs) and societal context factors (e.g., social cleavages, political conflicts, welfare state institutions) in explaining levels and 
forms of social capital (Kumlin and Rothstein, 2005; van Oorschot and Arts, 2005; Gelissen et al., 2012). Also, in this field of analysis, scholars have insisted on the fact that solidarity might involve group closure, and thus a bifurcation of solidarity relations. The notion of 'bonding capital' was coined in particular to point to the fact that individuals do tend to limit their relations of trust, reciprocity and solidarity to a reduced number of strong ties and intimate relations, thus fencing themselves off from their wider social environment, civil networks of engagement and other constituencies and targets (Putnam, 2000; Patulny and Svendsen, 2007). All in all, the study of solidarity has thus to consider the dark side of social closure.

As we can see, empirical research has provided a variety of insights. However, available knowledge still has to struggle with considerable limitations. First, empirical research has privileged the attitudinal dimension of solidarity, describing and explaining the disposition to help. Less attention has been paid to the question of what kind of behaviour constitutes solidarity. Second, the analysis of solidarity is not clearly distinguished from other related phenomena, and sometimes, the analysis considers altruism, care, philanthropy, empathy, help or support as potential synonyms. Hence, if solidarity is to be considered as a proper field of analysis, the specific traits of solidarity need to be highlighted. Third, much research has been undertaken with regard to public support of redistributive policies, but less knowledge is available on the level of interpersonal forms of solidarity. This is particularly true with respect to the international level, because there is almost no evidence about the European dimension of social solidarity. Undoubtedly there is abundant evidence with regard to the acceptance of the EU by its citizens, e.g., when referring to the debate about Euro-scepticism (Hooghe and Marks, 2007; Wessels, 2007; Lubbers and Scheepers, 2010; Boomgaarden et al., 2011) and public support for redistributive policies within the EU (Baute, Meulemann and Abts 2018; Gerhards et al., 2019). However, most research is unrelated to European civic or social solidarity in a stricter sense. Fourth, research lacks consideration of the various levels (micro, meso and macro) into which solidarity is structured and organised in modern societies. As we will argue in this chapter, European solidarity can only be properly understood and analysed when considering this multilevel structure.

\subsection{EUROPEAN SOLIDARITY: A CONCEPTUAL AND EMPIRICAL APPROACH}

What is needed is a sufficiently complex and consistent framework of analysis that allows for the study of solidarity in its various aspects and 
at its various levels of aggregation. Such a conceptual and theoretical mission, however, has to overcome various challenges. First, our object of analysis - European solidarity - refers to a spatial entity, to which solidarity is or might be attached. In this respect, we need to distinguish clearly between EU-related and European solidarity. Solidarity should be more palpable, once attributed to the European Union, and less clear when attributing it to the more diffuse notion of 'Europe', because the EU is an institutionalised spatial entity that expects cooperation and solidarity among its members (countries and citizens). The Lisbon Treaty, for instance, stipulates that the EU "shall promote economic, social and territorial cohesion, and solidarity among Member States" (TEU, Art. 3 ), a call that is restated in specific domains, such as asylum or security policies (TFEU, Art. 222). Even though these treaties primarily target the member states, they also provide a legal and institutional frame of reference for voicing and mobilising transnational solidarity below the state level. Following this line of reasoning, it might be advisable to speak of EU-related solidarity only. However, such an exclusive reference to EU solidarity is short-sighted, particularly if we look at interpersonal, civic forms of solidarity within and across European countries. In fact, while interstate solidarity is strongly tied to and patterned by formal membership in the EU, this is not necessarily the case when dealing with citizens and civil society organisations. Civic solidarity across borders might be smaller than the EU, when citizens and civil society organisations cooperate with other groups and support beneficiaries in neighbouring countries; but transnational solidarity might also go beyond EU member states, when considering that some European countries are not formal members of the EU and/or people living outside Europe. The insertion of Switzerland into the joint research is nurtured by the intention to combine an EU with a European-related analysis, because Switzerland is not formally a member of the EU, while it is tightly included in many of its treaties (e.g., the European Economic Area, the Schengen or Dublin space).

Second, our analytical framework has to do justice to the specificities of European solidarity, given that we are speaking of transnational practices and attitudes within a rather large and extensive community. In this regard, the analysis of European solidarity is particularly intriguing, because we might expect that horizontal types of European solidarity between citizens have to overcome problems associated with the (factual and/or perceived) size of Europe and/or the EU. The possibility of rooting solidarity in individual, face-to-face relations of help and exchange is rather limited, but not excluded, given the growing importance of mobility with regard to education, work or leisure. This might help to create informal networks based on ethnic background, culture or common interest (Glick Schiller et 
al., 1995; Morokvasic, 1999; Recchi and Favell, 2009). However, beyond these transnational networks or groups, it is to be expected that intermediate, mediated and institutionalised forms of solidarity are required in order to mobilise, stabilise and sustain transnational forms of civic solidarity within Europe. In this sense, an analysis of civil society and social movements is required, because these organisational fields might be essential in fuelling and organising European solidarity.

Finally, the analysis of spatially demarcated forms of solidarity has to take into consideration that social spaces are not necessarily separated and isolated entities. Transnational solidarity might be located within various spatial entities and address various spatial targets simultaneously. Some citizens, for instance, might proclaim the need to promote solidarity within their own country, within the EU and at the global level at the same time, while other citizens might prioritise solidarity with one entity (e.g., the nation-state), possibly at odds with others (e.g., Europe or the world). This means that the study of European solidarity should not be dissociated from the study of (complementary or antagonistic) claims for solidarity, e.g., towards the regions, the nation-state, other member states and/or the global level.

\subsubsection{Conceptual Matters: The Multidimensionality of 'Solidarity'}

Our conceptual and theoretical framework required a definition of solidarity that is able to identify the specificity of this concept, as compared to other notions like altruism, empathy, compassion, help or care. Following the conceptualisation of others (Bayertz, 1999; de Deken et al., 2006; Stjernø, 2012; Smith and Sorrell, 2014), we assume that solidarity has to do with these concepts, as Stjernø (2012: 88) proposed when defining solidarity as "the preparedness to share resources with others". However, we argue that this basic understanding is not enough, given that solidarity is not only a matter of philanthropic help towards others, of empathy or altruism. Solidarity is linked to reciprocal expectations and practices between people expressing sameness, togetherness and inclusiveness (Stjernø, 2012). Solidarity thus assumes the existence of (imagined) reference groups with some sort of 'membership', implying responsibilities for the others. Consequently, we propose the following definition: Solidarity is understood here as dispositions and practices of mutual help or support, be that by personal contributions or by the active support of activities of others, tied to informal and/or institutionalised groups. Solidarity entails relations of care and help, of altruism and empathy, but it is more than these concepts propose, because solidarity is grounded in group-bound rights and obligation (Scholz, 2008). Additionally, solidarity is much 
more than a purely individual phenomenon. Solidarity is an interpersonal, collective relation, because solidarity presupposes joint norms, expectations and practices. Solidarity might be apparent in individual acts and dispositions of help and care, but individual help and care are only acts of solidarity insofar as they are part of mutual relations of support. Finally, solidarity is grounded in mutual relations of support, because this mutuality is a practised manifestation of the normative underpinnings of solidarity: Solidarity builds (implicitly and/or explicitly) on the notion of rights, because people can expect to be helped; and solidarity entails an (implicit and/or explicit) notion of obligations, because people are expected to help each other.

This definition requires several clarifications. First, our conceptualisation does not necessarily take sides in the theoretical and normative debate between communitarianism and universalism (Rasmussen, 1990; Zürn and de Wilde, 2016), because it departs from a more analytical understanding of groups, and thus allows for variation with regard to the kind of social entities, narratives and ideologies involved (Arendt, 1963, 1972; Bayertz, 1999; Scholz, 2008). Citizens, civic initiatives and associations might cherish the idea of 'communitarian' solidarity, and thus they might believe that only members of established, natural or local communities are enmeshed in reciprocal relations of help and support and are thus eligible for common rights and obligations. But citizens, civic initiatives and associations might also promote the idea of 'universalistic' solidarity. They might thus proclaim that anybody - as part of their quality as a human being - can expect to receive help from others, and that everybody is at the same time called to provide support to others, given universal concepts of mutual rights and obligations. These particularist and universalist notions of solidarity apply to European solidarity as well. In fact, European solidarity can be defined as an attitude and behaviour in support of other Europeans, regardless of their national origin, but this definition leaves enough room for different normative orientations. European solidarity might be motivated by a communitarian understanding of membership, cherishing common identities, cultural traits, historical legacies and missions. However, it might also be encouraged by a more universalistic notion of European citizenship and a more open notion of (social, civic and political) rights and obligations of European citizens and/or residents. According to our understanding, European solidarity is an analytic concept that focuses on 'groups' with potentially different normative orientations.

Second, our own definition of solidarity stresses the need to consider attitudes and behaviours, particularly because solidarity entails notions of rights and obligations. So far, academic writing has tended to privilege attitudinal dispositions, in particular by focusing on the preparedness of 
citizens to share some of their resources with others (e.g., Stjernø, 2012: 2). Moreover, survey-based studies measure solidarity by the citizens' approval of re-distributional policies, and thus by readiness to devote some of their contributions or taxes to the needy (Svallfors, 1997; Fong, 2001; Amat and Wibbels, 2009; Rehm et al., 2012). This option has been used to measure European solidarity, e.g., in terms of fiscal help, redistributional measures and burden-sharing (Lengfeld et al., 2012; Gerhards et al., 2016; Baute et al., 2018; Gerhards et al., 2019). However, this focus on attitudes is not without problems. Taxes and contributions to social security programmes are compulsory and, hence, it is not completely clear what surveys measure when they ask respondents about their approval of redistributional policies - their general support of welfare states, or solidarity relations with specific groups of needy people. In other words: approval of social policies might not predetermine the readiness to commit individually in support of others. At the same time, social psychology has demonstrated that attitudes do not necessarily transform into actions, particularly if complex value and belief systems, structural impediments or individual costs are involved (Blumer, 1955; Festinger, 1964; Ajzen and Fishbein, 2005).

Third, standard measures of solidarity tend to privilege philanthropy or altruism (Skitka and Tetlock, 1993; Schroeder et al., 1995; van Oorschot, 2000). However, solidarity also has a political dimension. People demonstrate solidarity with others when participating in collective actions (e.g., public claims-making, political protests, communication campaigns) that strive to improve the situation of these groups by mobilising public support, committing stakeholders and/or changing public policies on their behalf (Cinalli, 2004; Balme and Chabanet, 2008; Baglioni and Giugni, 2014; Giugni and Grasso, 2015). In this sense, solidarity is a way of combating injustice and oppression suffered by specific groups or communities, on whose behalf individuals or organisations speak up (Bayertz, 1999: 16; Scholz, 2008). Solidarity is thus a means to enact (imagined) political communities with shared missions, ideas and beliefs. In these cases, European solidarity is already present when people in some countries are aware about and support public claims by citizens of other European countries, their organisational representatives or government officials, and when they actively help them to promulgate their views and claims.

This sensitivity to the political dimension of solidarity helps to acknowledge the contentious aspects of solidarity, because claims of solidarity might entail exclusive identities and obligations, and they might challenge the status quo on behalf of specific groups against others (Arendt, 1963, 1972; Reshaur, 1992; Balibar, 2004). For a systematic analysis of European solidarity, this political dimension seems crucial. Populist groups and parties speak out on behalf of exclusive, national communities, often claiming 
that solidarity with weak compatriots comes before solidarity with others, thus downplaying the legal, political or moral obligations nation-states have as members of the European Union; pro- or pan-European groups instead will speak out on behalf of social groups and member countries most affected by the crises, possibly as part of a struggle to improve the situation of weak compatriots, too. In these terms, particularistic and universalistic solidarity claims are in conflict with each other.

Fourth, the definition of solidarity has to be open due to the variety of manifestations. Two main issues need to be taken into consideration. On the one hand, solidarity can be motivated by very different norms, rules and expectations. Mau (2006) and Lengfeld et al. (2015), for instance, have highlighted different reasons and motivations for supporting European solidarity. For some, interstate support in times of crisis is a necessary correlate of common duties and moral obligations, for others just a consequence of reciprocal relations of mutual help, while still others define it as a rational (utilitarian) investment for the benefit of member states, donors included. In this sense, solidarity can be patterned along different levels of compassion and abnegation, reciprocity, cooperation and interdependency (Malamoud, 2015). On the other hand, we have to consider that solidarity is a relative phenomenon, i.e., conditional on membership of specific communities and groups. Undoubtedly, solidarity can be a value tied to abstract groups or entities (i.e., humankind), and thus associated with a universalistic notion of generalised support (Brunkhorst, 1997; Balibar, 2004). In survey-based research, this solidarity is measured as a generalised, civic disposition of help not tied back to any particular group or conditionality (Svallfors, 1997; Fong, 2001; Amat and Wibbels, 2009; Rehm et al., 2012). However, empirically speaking, particularism is tightly associated with solidarity, too. As shown by empirical analyses, solidarity seems to be patterned by the assumed 'deservingness' of various social groups, thus favouring elderly and disabled people over the unemployed, the poor and immigrants (van Oorschot, 2006: 23). Conditionality is not necessarily restricted to social groups, but can apply to countries as well; consider, for example, low rates of public German support for fiscal help to the Greek government, in comparison with German support towards Ireland, Italy and Spain (Lengfeld et al., 2012).

\subsubsection{Analytical and Explanatory Matters: Multi-Layered Solidarity}

The conceptual clarifications help to define solidarity as a relation of mutual support linked to (informal/formalised, imagined/institutionalised, universal/particular) groups. This conceptual discussion requires further development, because solidarity might be organised and institutionalised 
at different levels of aggregation, particularly if we are speaking about complex social systems, such as national societies, and even more so, Europe or the European Union. As we will show, it is advisable to distinguish three levels of aggregation and organisation. Solidarity can be organised at the interpersonal level (micro), at the level of organisations and organisational fields (meso), and at the level of political entities such as welfare states and public spheres (macro).

This differentiation of various levels of analysis is necessary to empirically map and describe solidarity in a more comprehensive manner. Additionally, however, we need to differentiate our analytic framework also with regard to the theoretical approaches used by previous studies in order to identify and explain types, processes and structures of solidarity (Doreian and Fararo, 1998). In fact, our research was not only geared to describe levels and forms of solidarity within Europe, but also to decipher causes, correlates and consequences. In this regard, we developed a multidimensional framework of analysis along two dimensions. On the one side, we argue that solidarity is socially produced and reproduced at various levels of aggregation, which means that solidarity will most probably be shaped by different forces at the micro, meso and macro levels of analysis. This multidimensionality requires an analytical framework that makes use of available theories and explanatory models for each of the three levels. On the other hand, previous analyses of solidarity have been related to theories either highlighting objective structures and mechanisms, or privileging ideational factors and communicative processes, as suggested by Archer (1996) who distinguishes between structures and social actors, and cultures and cultural actors. Existing theories have tended to privilege one of these approaches when dealing with solidarity at the micro, meso and macro levels. Table 1.1 summarises our analytical framework, by listing the various levels of analysis and the theoretical approaches. On this basis,

\section{Table 1.1 Explanatory strategies in the study of (European) solidarity}

\begin{tabular}{lcc}
\hline & social-structural factors & cultural-ideational \\
\hline micro level: individual & socio-demographic & preferences, identifications, \\
solidarity & determinants & values and ideas \\
meso level: organised & organisational fields: & organisational spheres: \\
solidarity & resources, networks and & frames, ideologies, and \\
& cleavages & identities \\
macro level: & societal structures: legal & cultural structures: belief \\
institutionalised & and socio-economic & systems, institutions, \\
solidarity & contexts, welfare & discourses \\
& institutions and policies & \\
\hline
\end{tabular}


we can identify for each cell which explanatory factors should be taken into consideration. Overall, it provides us with a heuristic instrument to develop a multidimensional framework of analysis.

In the following, we wish to develop the theoretical arguments of this heuristic model by moving from the micro to the macro level, arguing for the necessity of the former levels of analysis to be embedded in the latter ones. Our theoretical journey will make use of previous research in order to highlight the specificities and potential of each approach.

A first focus of explanatory strategies has been the micro level of individual solidarity. Previous research has tended to privilege this level. Research has been interested in group-internal solidarity and the rules guiding internal exchange relations and group cohesion (Hechter, 1988; Markovsky and Lawler, 1994; Komter, 2005), in attitudes and practices of compassion, help and altruism (Skitka and Tetlock, 1993; Schroeder et al., 1995; Scheepers and Grotenhuis, 2005), and in understanding the citizens' support of the welfare states and their redistributive policies support (Blekesaune and Quadagno, 2003; Brooks and Manza, 2007). Regarding explanatory strategies, the analysis has tended to privilege the two approaches introduced before. In the first instance, we can refer to authors who explain levels and forms of solidarity with reference to resources, objective interests and rational choices (Hechter, 1988). Solidarity is a choice reflecting the individuals' socio-economic situation and the related cost-benefit calculations. We should thus expect that solidarity is more diffused among the most vulnerable and invulnerable social strata of the population (van Setten et al., 2017), as it implies more gains than losses for both sides. Recipients might suffer stigmatisation, once they disclose their neediness, but they gain financial help, while donors have to share their financial resources, but gain social recognition. But do these considerations apply to Europe? Solidarity within Europe might be more conditional and complex, and possibly also pre-structured by interlocking group memberships. Vulnerable social groups in affluent societies, for instance, might oppose the sharing of public funds with poorer countries, while privileged groups might expect less social recognition from innerEuropean redistribution of wealth.

These observations lead to the second strand of micro-level analyses, because they highlight that solidarity choices will most probably be predetermined or mediated by subjective perceptions, emotions, values and belief systems (Markovsky and Lawler, 1994; Komter, 2005). Research on solidarity has identified a number of these factors such as political allegiances (Skitka and Tetlock, 1993), religion (Abela, 2004; Stegmueller et al., 2012; Lichterman, 2015), post-materialism (Inglehart and Rabier, 1978), loyalties to ethnic groups (Alesina and Glaeser, 2004; Luttmer, 
2001), beliefs about the causes of income (Fong, 2001), or perceptions of deservingness (van Oorschot, 2006). These factors will most probably shape levels of individual solidarity at the local and national levels. However, this does not fully open the door to an understanding of the subjective and ideational determinants of European solidarity as such, given the fact that the EU is a much more multicultural entity than most member states are. Consequently, we must assume that individual solidarity within the EU is also shaped by the following two factors. On the one hand, we might expect that European solidarity is conditional on the development of identifications with the European Union, either as unique identifications and/or as elements of multiple (local, national, transnational) identities. On the other hand, we might assume that solidarity within the EU is conditional on spatial and/or cultural closeness, i.e., limiting individual solidarity between countries that are perceived to be (spatially, socially, culturally, historically) closer to each other.

Overall, we argue that a research strategy centred on individuals might be an adequate way of operationalising solidarity empirically, but an incorrect way of explaining solidarity theoretically. In fact, findings about individual dispositions or acts of solidarity tend to argue that solidarity transcends the individual, namely by referring implicitly to group norms and beliefs, joint expectations and responsibilities among group members. In this sense, solidarity is a collective phenomenon before it becomes an individual one. This is the reason why the study of individual solidarity needs to be embedded in an inquiry of the meso and macro structures.

Accordingly, we propose to move to the meso level, following the assumption that solidarity very often requires some sort of organisation. Undoubtedly, solidarity is also a matter of individual and spontaneous acts of help within face-to-face situations. However, as soon as we transcend this level of isolated activities, informal networks and interactions within everyday life, we move into what research about civil societies and social movements has identified as the determinants and properties of collective action (Smith et al., 1997; Giugni and Passy, 2001). Solidarity demands, on the one hand, the pooling of resources, the coordination of individual activities, the provision of incentives and sanctions (Hirsch, 1986), while, on the other hand, building on the promotion of shared behavioural norms, ideas and identities is also a requirement (Minkoff, 1997; Hunt and Bendorf, 2004). Individual acts of solidarity will very often be motivated, directed and spurred on by the affiliation, membership or adherence to specific organisations and movements. The latter provide incentives to participate, role models for acting, and norms and identities to motivate and/ or justify solidarity, e.g., when referring to membership fees and charitable donations, joint political protests, events of claims-making. 
These observations are particularly relevant for European solidarity, given the fact that we are analysing rather complex and territorially extended forms of collective actions (Batliwala, 2002; Smith, 2002). European solidarity will most probably be more dependent on organisation as a process, and on organisations as entrepreneurial entities. In this regard, it seems indispensable to link the study of European solidarity to the analysis of transnational solidarity organisations and organisational fields (Bandy and Smith, 2005; Balme and Chabanet, 2008; della Porta and Caiani, 2011; Baglioni and Giugni, 2014). On the one hand, we hypothesise that European solidarity is clearly dependent on the development of transnational fields or networks of civil society and social movement organisations, which increase connectivity and diffusion processes, mobilise and organise constituencies, and define and circulate common discourses and identities. Consequently, we assume that European solidarity will most probably be structured differently in various issue fields and policy domains, mirroring the diverse organisational strength and mobilisation power of the various organisational fields. On the other hand, we have to take into account that organisational fields are patterned along cleavages, conflicts and oppositions, too, which are of particular importance to better understand the contentiousness of European solidarity. In fact, in many issue fields and policy domains at national and EU level, we see the emergence of populist, nationalist and xenophobic groups, political parties and movements (Kriesi, 2012; Wodak et al., 2013; Gómez-Reino and Llamazares, 2013), which in many instances oppose attempts to mobilise and institutionalise measures of European solidarity. Here, we refer back to our argument that solidarity is highly political in the sense of implying (competing) notions of (imagined) groups or communities (e.g., regional, national, European) with opposing memberships, missions and ideas. In organisational terms, we hypothesise that the development of European solidarity at the individual and collective levels is therefore strongly dependent on organisational fields, their internal cleavages and contentions.

Third, the analysis of solidarity recurrently heads towards the macro level, and here, social theories tend to privilege either structural, institutional and/or cultural dimensions. Here, the range of potential theoretical explanations is very wide, and thus we need to restrict ourselves to those most pertinent to our analysis. Of lesser importance are approaches committed to the sociological modernisation theory, which stress the emergence of 'organic' solidarities in functionally differentiated societies (Parsons, 1951; Durkheim, 1997), post-materialistic orientations within economically affluent societies (Inglehart and Rabier, 1978), and post-nationalistic and cosmopolitan orientations in times of reflexive modernity (Beck et al., 1994). All of them tend to stress unidirectional and linear developments, 
thus disregarding the contentiousness of European solidarity. Much more relevant are theories dealing with institutionalised forms of solidarity in terms of welfare states, public policies and constitutional rights.

In fact, solidarity is a political idea and a legal norm institutionalised by the emerging welfare states in order to regulate the social rights and obligations of their citizens. The principle of solidarity is thus woven into constitutions (Brunkhorst, 2005; Bellamy et al., 2006; Ross and Borgmann-Prebil, 2010; Dalessio, 2013), but also in policy fields and specific policy measures, as research on welfare regimes and social policies argues (Esping-Anderson et al., 2002; de Bùrca, 2005; Morel et al., 2012). The extent to which citizens can count on the solidarity of the state and citizenry thus depends on the range and kind of social rights and entitlements guaranteed by public policies, on the way social policies are funded and administered, and on the way citizens claim their rights in case of dissent. An analysis of legal frameworks and institutional settings is not only important to understand the levels and forms of institutionalised solidarity, though. It also seems pertinent with regard to the analysis of civic solidarity at the level of individual citizens and civil societies. Research has shown that different welfare regimes provide different opportunities and constraints for non-profit associations, private welfare provision, or volunteering (Evers, 1995; Anheier and Salamon, 1999; Bauer et al., 2013); and they shape the normative expectations addressed to their citizens and thus potentially also their attitudes and practices (Banting and Kymlicka, 2017). Before this backdrop, we might hypothesise that the uneven institutionalisation of solidarity within the legal framework and public policies at the national and EU level will have implications for the uneven development of solidarity at the level of citizens and civil societies. Research has given examples of how a benevolent welfare state with strong policies of redistribution might spur on crowding out effects on private philanthropy (Abrams and Schitz, 1978; Frey, 1998; Nikolova, 2014). In this vein, we can assume that the weak institutionalisation of solidarity at the EU level might condition crowding in effects on civic solidarity, particularly in times of accelerating crisis and urgent need for remedial actions.

References to the legal and institutional framework are incomplete if we do not take into consideration the constitutive role of the public sphere as an arena of contestation and deliberation. Law and public policies mirror, to a certain extent, ideas, beliefs and values cherished within the public sphere (Habermas, 1996: 76; 2013), which means that also institutionalised solidarity is constantly constructed and reproduced through public narratives, ideologies and discourses (Brown and Gilman, 1960; Calhoun, 2002; Pensky, 2008). Our references to the macro level would thus remain incomplete if we ignored the decisive role of the mass media as an arena 
for the formation of collective opinions and ideas about legitimate solidarity (Mylonas, 2012; Papathanassopoulos, 2015). This role has been evidenced in previous episodes of the European integration process (e.g., Statham and Trenz, 2013), but is particularly important when considering the impact of the European crisis on public debates at the European and national levels. Studies have dealt with the Great Recession since 2008 and have shown that the crisis increased the intensity of conflicts within the public sphere, thus highlighting the disagreements between different governments about the necessary measures to combat the (budgetary, economic, and social) consequences of the crisis (Wilde et al., 2013). Given the fact that the mass media are still strongly attached to different language areas, political systems and specific national audiences (SchulzForberg and Stråth, 2010; Boomgaarden et al., 2013), it is very probable that the propagated notions of European solidarity will structurally mirror the antagonistic positions of member states within the European crisis. Additionally, research on public debates about the so-called refugee crisis of 2015 and 2016 evidences that public debates diverge between European member states also in regard to the degree of contentiousness and polarization (Berry et al., 2016). They show that public debates play a role both in mobilizing and weakening European solidarity.

Overall, we thus propose a conceptual and theoretical framework that includes various analytical dimensions and explanatory factors. Beyond a purely additive rationale, this framework insists on the need to analyse the embeddedness of individual and organised forms of solidarity within the meso and macro levels of collective constraints and opportunities, cultural meanings and discourses. In fact, we assume that the degree and the forms of European solidarity among citizens will be shaped by their sociodemographic traits and immediate social environments (e.g., gender, social class, political and/or religious allegiances), but also by the availability of organisations (e.g., self-help groups, welfare associations, social movement organisations), and the transnational structures of organisational fields. Finally, individual solidarity will also be influenced by constitutional and institutional opportunities and constraints on social solidarity, and it will most probably be impacted by public discourses on legitimate and accepted forms of (European) solidarity (Lindenberg, 1998). In fact, individual citizens might withdraw from solidarity in reaction to proliferating public mistrust against the addressees of help; they might also be less inclined due to flourishing reservations against civic organisations or public authorities channelling (financial) contributions, or they might abstain because of a mushrooming scepticism about the value of helping others in times of crisis. Charitable or political organisations might find it harder to mobilise individual, corporate or state support for their work in times of shrinking 


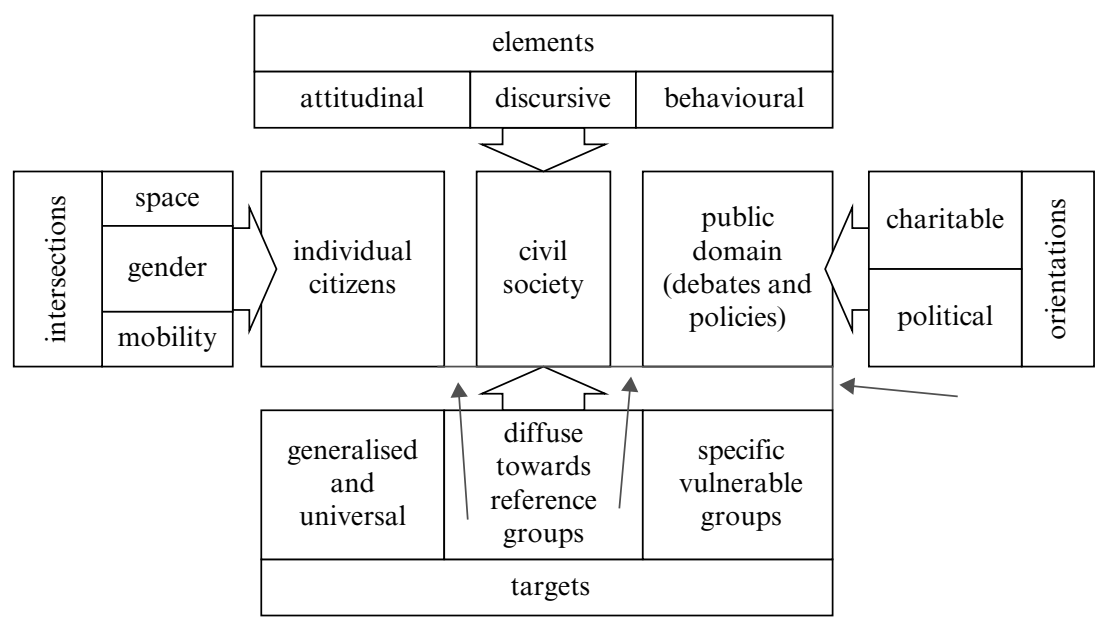

Figure 1.1 European solidarity as a multidimensional phenomenon

institutional and/or interpersonal trust and eroding public commitment to (transnational) solidarity.

In the following chapters, we will present the main findings of our joint research effort along the analytic framework presented here. The major challenge of this research was the under-developed body of knowledge we had to build upon. In fact, while the study of solidarity is as old as the social sciences, we have very few studies focusing on European solidarity, particularly in regard to social and civic social solidarity across borders. This book aims to close part of this knowledge gap, by providing systematic data on the levels and forms of solidarity within Europe, and by engaging in in-depth analyses of the factors promoting and inhibiting civic solidarity. It is structured along the various levels of analysis identified as relevant forms and arenas of solidarity formation: the level of citizens and interpersonal solidarity (micro), the level of civic groups and interorganizational fields (meso), and the level of public discourses and legal systems (macro).

Chapter 2 by Maria Grasso and Christian Lahusen presents the findings from a survey carried out on individual citizens. Its results highlight that a considerable share of the population in our eight countries is committed to solidarity practices and approves of redistribution. However, European solidarity is the weakest element in the array of target groups supported by the respondents. The third and fourth chapters deal with organised forms of transnational solidarity. In Chapter 3, Maria Kousis, Angelos Loukakis, Maria Paschou and Christian Lahusen focus on the grass-roots level of local initiatives, groups and organisations. In Chapter 4, Simone 
Baglioni and Tom Montgomery focus on the national and supra-national levels. Both chapters identify a remarkable range of initiatives and show that citizen groups and associations are strongly committed in responding to societal grievances, not least those caused by the various crises affecting the EU and its member states. At the same time, they show that the organisational fields within the various countries are not strongly transnationalised in terms of cross-national activities. Organised solidarity, even when committed to a European mission and scope of activities, is marked by a decentralised organisational structure.

The following chapters move to the macro level of analysis. Veronica Federico presents the evidence gathered through the analysis of national constitutions, public policies and court rulings in Chapter 5. She shows that solidarity is a legal principle nurturing the legal systems of all countries, but that this principle is unevenly institutionalised both in the eight countries and the three issue-fields under analysis (migration, unemployment and disabilities). Moreover, we identify regressive moments that are due to the various crises affecting Europe since 2008. Chapters 6 and 7 portray public discourses on the so-called refugee crisis between mid-2015 and early 2016. Manlio Cinalli, Olga Eisele, Verena K. Brändle and Hans-Jörg Trenz focus on public claims publicised within national media, and they inquire into comments by news users. The analysis shows that solidarity is indeed a key issue within the news coverage and the news usage of readers. Moreover, they identify the momentous emergence of Europe-wide solidarity during the summer of 2015, but also regressive trends since then. The concluding Chapter 8 by Christian Lahusen addresses the common themes and findings of this book. It argues that European solidarity is firmly rooted within citizenry, civil societies and social movements, and public policies and discourses. At the same time, however, findings show that European solidarity is exposed to conflicts and subject to fluctuations. Our research thus evidences that European solidarity is a societal force, but one that is, however, contested and fragile in nature.

\section{REFERENCES}

Abela, A. M. (2004). Solidarity and Religion in the European Union: A Comparative Sociological Perspective. In P. Xuereb (ed.), The Value(s) of a Constitution for Europe. Malta: European Documentation and Research Centre, pp. 71-101.

Abrams, B. A. and Schitz, M. D. (1978). The 'crowding-out' effect of governmental transfers on private charitable contributions. Public Choice, 33: 29-39.

Ajzen, I. and Fishbein, M. (2005). The Influence of Attitudes on Behavior. In D. Albarracín, B. T. Johnson and M. P. Zanna (eds), The Handbook of Attitudes. Mahwah, NJ: Erlbaum, pp. 173-221. 
Alesina, A. and Giuliano, P. (2011). Preferences for Redistribution. In J. Benhabibi, A. Bisin and M. Jackson (eds), Handbook of Social Economics. San Diego, CA: North-Holland, pp. 93-132.

Alesina, A. and Glaeser, E. (2004). Fighting Poverty in the US and Europe: A World of Difference. Oxford: Oxford University Press.

Alexander, J. C. (1980). Core Solidarity, Ethnic Outgroup, and Social Differentiation: A Multidimensional Model of Inclusion in Modern Societies. In J. Dofny (ed.), National and Ethnic Movements. London: Sage, pp. 5-28.

Amat, F. and Wibbels, E. (2009). Electoral Incentives, Group Identity and Preferences for Redistribution. Instituto Juan March de Estudios e Investigaciones Working Paper 246.

Anheier, H. K. and Salamon, L. M. (1999). Volunteering in cross-national perspective: Initial comparisons. Law and Contemporary Problems, 62: 43-66.

Apostoli, A. (2012). La svalutazione del principio di solidarietà. Milan: Giuffré Editore.

Archer, M. S. (1996). Culture and Agency: The Place of Culture in Social Theory. Cambridge: Cambridge University Press.

Arendt, H. (1963). On Revolution. New York: Viking.

Arendt, H. (1972). Crises of the Republic. New York: Harcourt Brace Jovanovich.

Baglioni, S. and Giugni, M. (eds) (2014). Civil Society Organizations, Unemployment, and Precarity in Europe: Between Service and Policy. Basingstoke: Palgrave Macmillan.

Balibar, É. (2004). We, the People of Europe: Reflections on Transnational Citizenship. Princeton, NJ: Princeton University Press.

Balibar, É. (2014). Equaliberty: Political Essays. Durham, NC: Duke University Press.

Balme, R. and Chabanet, D. (2008). European Governance and Democracy: Power and Protest in the EU. Lanham, MD: Rowman \& Littlefield.

Bandy, J. and Smith, J. (2005). Coalitions across Borders: Transnational Protest and the Neoliberal Order. Lanham, MD: Rowman \& Littlefield.

Banting, K. G. and Kymlicka, W. (eds) (2006). Multiculturalism and the Welfare State: Recognition and Redistribution in Contemporary Democracies. Oxford: Oxford University Press.

Banting, K. G. and Kymlicka, W. (eds) (2017). The Strains of Commitment: The Political Sources of Solidarity in Diverse Societies. Oxford: Oxford University Press.

Batliwala, S. (2002). Grassroots movements as transnational actors: Implications for global civil society. Voluntas: International Journal of Voluntary and Nonprofit Organizations, 13(4): 393-409.

Bauer, T. K., Bredtmann, J. and Schmidt, C. M. (2013). Time vs. money - the supply of voluntary labour and charitable donations across Europe. European Journal of Political Economy, 32: 80-94.

Baute, S., Meuleman, B. and Abts, K. (2018). Welfare state attitudes and support for social Europe: Spillover or obstacle? Journal of Social Policy, 1-19.

Bayertz, K. (1999). Four Uses of 'Solidarity'. Solidarity - Philosophical Studies in Contemporary Culture Volume 5, 1999, pp. 3-28.

Beck, U., Giddens, A. and Lash, S. (1994). Reflexive Modernization: Politics, Tradition and Aesthetics in the Modern Social Order. Stanford, CA: Stanford University Press.

Beck, U. and Grande, E. (2007). Cosmopolitan Europe. Cambridge: Polity Press. 
Bellamy, R., Castiglione, D. and Shaw, J. (2006). Making European Citizens: Civic Inclusion in a Transnational Context. Basingstoke: Palgrave Macmillan.

Berry, M., Garcia-Blanco, I. and Moore, K. (2016). Press coverage of the refugee and migrant crisis in the EU: A content analysis of five European countries. Project Report. Geneva: United Nations High Commissioner for Refugees, available at http://www.unhcr.org/56bb369c9.html, last accessed 27 September 2018.

Blekesaune, M. and Quadagno, J. (2003). Public attitudes toward welfare state policies: A comparative analysis of 24 countries. European Sociological Review, 19(5): 415-27.

Blumer, H. (1955). Attitudes and the social act. Social Problems, 3: 59-65.

Boomgaarden, H. G., Schuck, A. R. T., Elenbaas, M. and de Vreese, C. H. (2011). Mapping EU attitudes: Conceptual and empirical dimensions of Euroscepticism and EU support. European Union Politics, 12(2): 241-66.

Boomgaarden, H. G., de Vreese, C. H., Schuck, A. R. T., Azrout, R., Elenbaas, M., Van Spanje, J. H. P. and Vliegenthart, R. (2013). Across time and space: Explaining variation in news coverage of the European Union. European Journal of Political Research, 52(5): 608-29.

Börner, S. (2013). Belonging, Solidarity and Expansion in Social Policy. Basingstoke: Palgrave Macmillan.

Börner, S. (2014). From National to European Solidarity? The Negotiation of Redistributive Spaces. In S. Börner and M. Eigmüller (eds), European Integration: Processes of Change and the National Experience. Basingstoke: Palgrave Macmillan, pp. 166-88.

Bourdieu, P. (1986). The Forms of Capital. In J. Richardson (ed.), Handbook of Theory and Research for the Sociology of Education. New York: Greenwood, pp. 241-58.

Brooks, C. and Manza, J. (2007). Why Welfare States Persist: The Importance of Public Opinion in Democracies. Chicago, IL: University of Chicago Press.

Brown, E. and Ferries, J. M. (2007). Social capital and philanthropy: An analysis of the impact of social capital on individual giving and volunteering. Nonprofit and Voluntary Sector Quarterly, 36(1): 85-99.

Brown, R. and Gilman, A. (1960). The pronouns of power and solidarity. In T. A. Sebeok (ed.), Style in Language. Cambridge, MA: MIT Press, pp. 253-76.

Brunkhorst, H. (1997). Solidarität unter Fremden. Frankfurt am Main: Fischer.

Brunkhorst, H. (2005). Solidarity: From Civic Friendship to Global Legal Community. Cambridge: Cambridge University Press.

Calhoun, C. J. (2002). Imagining Solidarity: Cosmopolitanism, Constitutional Patriotism, and the Public Sphere. Public Culture, 14(1): 147-71.

Chan, J. and Chan, T. H. (2006). Reconsidering social cohesion: developing a definition and analytical framework for empirical research. Social Indicators Research, 75: 273-302.

Cinalli, M. (2004). Horizontal networks vs. vertical networks in multi-organisational alliances: A comparative study of the unemployment and asylum issue-fields in Britain. EurPolCom, 8(4): 1-31.

Dalessio, T. O. (2013). The social dimension of EU citizenship: A castle in the air or construction gone wrong? German Law Journal, 14: 869-88.

de Bùrca, G. (2005). EU Law and the Welfare State: In Search of Solidarity. Oxford: Oxford University Press.

de Deken, J., Ponds, E. and van Riel, P. (2006). Social Solidarity. In G. L. Clard and 
A. H. Munnell (eds), The Oxford Handbook of Pensions and Retirement Income. Oxford: Oxford University Press, pp. 141-60.

Delanty, G. and Rumford, C. (2005). Rethinking Europe: Social Theory and the Implications of Europeanization. Abingdon and New York: Routledge.

Delhey, J. (2007). Do enlargements make the European Union less cohesive? An analysis of trust between EU nationalities. Journal of Common Market Studies, 45(2): 253-79.

della Porta, D. (ed.) (2018). Solidarity Mobilizations in the 'Refugee Crisis': Contentious Moves (Palgrave Studies in European Political Sociology). Basingstoke: Palgrave Macmillan.

della Porta, D. and Caiani, M. (2011). Social Movements and Europeanization. Oxford: Oxford University Press.

della Porta, D. and Mattoni, A. (2014). Spreading Protest: Social Movements in Times of Crisis. Colchester, UK: ECPR Press.

Dobson, L. (2012). Supranational Citizenship. Oxford: Oxford University Press.

Doreian, P. and Fararo, T. (eds) (1998). The Problem of Solidarity: Theories and Models. Amsterdam: Gordon and Breach Publishers.

Durkheim, E. (1997). The Division of Labor in Society. New York: Free Press.

Eder, K. (2005). National Identities and Collective Memory in an Enlarged Europe. In W. Spohn and K. Eder (eds), Collective Memory and European Identity: The Effects of Integration and Enlargement. Aldershot: Ashgate, pp. 1-14.

Esping-Andersen, G., Gallie, D., Hemerijk, A. and Myers, J. (2002). Why We Need a New Welfare State. Oxford: Oxford University Press.

Evers, A. (1995). Part of the welfare mix: The third sector as an intermediate area. Voluntas: International Journal of Voluntary and Nonprofit Organizations, 6(2): 159-82.

Featherstone, D. (2012). Solidarity: Hidden Histories and Geographies of Internationalism. London: Zed Books.

Festinger, L. (1964). Behavioral support for opinion change. The Public Opinion Quarterly, 28: 404-17.

Fligstein, N. (2008). Euroclash: The EU, European Identity and the Future of Europe. Oxford: Oxford University Press.

Fong, C. (2001). Social Preferences, Self-Interest, and the Demand for Redistribution. Journal of Public Economics, 82(2): 225-46.

Frey, B. (1998). Institutions and Morale: The Crowding-Out Effect. In A. Ben-Ner and L. Putterman (eds), Economics, Values, and Organization. Cambridge: Cambridge University Press, pp. 437-60.

Galpin, C. (2012). Unity or Disunity? Conceptualising Change in European Identity Discourses during the Eurozone Crisis. Paper presented at the workshop "European Identity in Times of Crisis: Sociological Perspectives on Identification with Europe in Turbulent Times". 11-12 June 2012. European University Institute, Florence, Italy.

Gelissen, J., Wim, J. H., van Oorschot, W. and Finsveen, E. (2012). How does the welfare state influence individuals' social capital? Eurobarometer evidence on individuals' access to informal help. European Societies: 1-25.

Gerhards, J. and Lengfeld, H. (2015). European Citizenship and Social Integration in the European Union. London and New York: Routledge.

Gerhards, J., Lengfeld, H. and Häuberer, J. (2016). Do European citizens support the idea of a European welfare state? Evidence from a comparative survey conducted in three EU member states. International Sociology, 31(6): 677-700. 
Gerhards, J., Lengfeld, H., Ignácz, Z. S., Kley, F. K. and Priem, M. (2018). How strong is European solidarity? Berlin Studies on the Sociology of Europe (BSSE), 37: $1-37$.

Gerhards, J., Lengfeld, H., Ignácz, Z., Kley, F. K. and Priem, M. (2019). European Solidarity in Times of Crisis: Insights from a Thirteen-Country Survey. London/ New York: Routledge.

Giugni, M. and Grasso, M. (eds) (2015). Austerity and Protest: Citizens' Reactions to the Economic Crisis and Policy Responses to It. Farnham: Ashgate.

Giugni, M. and Passy, F. (2001). Political Altruism? Solidarity Movements in International Perspective. Lanham, MD: Rowman \& Littlefield.

Glick Schiller, N., Basch, L. and Szanton-Blanc, C. (1995). From immigrant to transmigrant: Theorizing transnational migration. Anthropological Quarterly, 68(1): 48-63.

Gómez-Reino, M. and Llamazares, I. (2013). the populist radical right and European integration: A comparative analysis of party-voter links. West European Politics, 36(4): 789-816.

Guild, E., Gortázar Rotaeche, C. and Kostakopoulou, D. (eds) (2013). The Reconceptualization of European Union Citizenship. Leiden: Martinus Nijhoff.

Habermas, J. (1996). Between Facts and Norms: Contributions to a Discourse Theory of Law and Democracy. Cambridge, MA: MIT Press.

Habermas, J. (2013). Im Sog der Technokratie. Ein Plädoyer für europäische Solidarität. In J. Habermas, Kleine Politische Schriften XII. Frankfurt am Main: Suhrkamp.

Hechter, M. (1988). Principles of Group Solidarity. Berkeley: University of California Press.

Hirsch, E. L. (1986). The creation of political solidarity in social movement organizations. The Sociological Quarterly, 27(3): 373-87.

Hooghe, L. and Marks, G. (2007). Sources of Euroscepticism. Acta Politica, 42(2): $119-27$.

Hunt, S. A. and Benford, R. D. (2004). Collective Identity, Solidarity, and Commitment. In D. A. Snow, S. A. Soule and H. Kriesi (eds), The Blackwell Companion to Social Movements. Oxford: Blackwell, pp. 433-57.

Hutter, S. and Grande, E. (2014). Politicizing Europe in the national electoral arena: A comparative analysis of five west European countries, 1970-2010. Journal of Common Market Studies, 52(5): 1002-18.

Inglehart, R. and Rabier, J. R. (1978). Economic uncertainty and European solidarity: Public opinion trends. The Annals of the American Academy of Political and Social Science November, 440(1): 66-97.

Isin, E. and Saward, M. (2013). Enacting European Citizenship. Cambridge: Cambridge University Press.

Jacobs, F. G. (2007). Citizenship of the European Union: A legal analysis. European Law Journal, 13(5): 591-610.

Jeannotte, M. S. (2000). Social Cohesion around the World: An International Comparison of Definitions and Issues. Paper SRA-390.

Komter, A. E. (2005). Social Solidarity and the Gift. Cambridge: Cambridge University Press.

Kriesi, H. (2012). The political consequences of the financial and economic crisis in Europe: Electoral punishment and popular protest. Swiss Political Science Review, 18(4): 518-22.

Kriesi, H., Grande, E., Lachati, R., Dolezal, M., Bornschier, S. and Frey, T. 
(2006). Globalization and the transformation of the national political space: six European countries compared. European Journal of Political Research, 45(6): 921-56.

Kriesi, H. and Pappas, T. S. (eds) (2015). European Populism in the Shadow of the Great Recession. Colchester: ECPR Press.

Krouwel, A. and Abts, K. (2007). Varieties of Euroscepticism and populist mobilization: Transforming attitudes from mild Euroscepticism to harsh Eurocynicism. Acta Politica, 42(2): 252-70.

Kumlin, S. and Rothstein, B. (2005). Making and breaking social capital: The impact of welfare-state institutions. Comparative Political Studies, 38(4): 339-65.

Lahusen, C. and Grasso, M. T. (2018). Solidarity in Europe - European solidarity: An introduction. In C. Lahusen and M. T. Grasso (eds), Solidarity in Europe: Citizens' Responses in Times of Crisis. Basingstoke: Palgrave Macmillan, pp. $1-18$.

Lengfeld, H., Schmidt, S. and Häuberer, J. (2012). Solidarität in der europäischen Fiskalkrise: Sind die EU-Bürger zu finanzieller Unterstützung von hoch verschuldeten EU-Ländern bereit? Erste Ergebnisse aus einer Umfrage in Deutschland und Portugal. University of Hamburg: Hamburg Reports on Contemporary Societies No. 5/2012.

Lengfeld, H., Schmidt, S. and Häuberer, J. (2015). Is there a European Solidarity? Attitudes Towards Fiscal Assistance for Debt-Ridden European Union Member States. Leipzig: Report of the Department of Sociology No. 67.

Lichterman, P. (2015). Religion and Social Solidarity: A Pragmatist Approach. In L. Hustinx, J. von Essen, J. Haers and S. Mels (eds), Religion and Volunteering: Complex, Contested and Ambiguous Relationships. Cham: Springer, pp. 241-61.

Lindenberg, S. (1998). Solidarity: Its Microfoundations and Macrodependence: A Framing Approach. In P. Doreian and T. Fararo (eds), The Problem of Solidarity: Theories and Models. Amsterdam: Gordon and Breach Publishers, pp. 282-328.

Lubbers, M. and Scheepers, P. (2010). Divergent trends of Euroscepticism in countries and regions of the European Union. European Journal of Political Research, 49(6): 787-817.

Luttmer, B. (2001). Group loyalty and the taste for redistribution. Journal of Political Economy, 109(3): 500-528.

Malamoud, C. (2015). En quete de l'idée de solidarité dans l'Indie ancienne. In A. Supiot (ed.), La Solidarité. Enquete sur un principe juridique, Paris: Odile Jacob, pp. 127-38.

Markovsky, B. and Lawler, E. J. (1994). A New Theory of Group Solidarity. In B. Markovsky, K. Heimer and J. O'Brien (eds), Advances in Group Processes. Greenwich, CT: JAI Press, pp. 113-37.

Mau, S. (2006). Forms and Prospects of European Solidarity. In N. Karangiannis (ed.), European Solidarity. Liverpool: Liverpool University Press, pp. 129-46.

Maull, H. W. (2009). Forschungsfragen und Forschungslücken. In S. Harnisch, H. W. Maull, and S. Schieder (eds), Solidarität und internationale Gemeinschaftsbildung. Beiträge zur Soziologie der internationalen Beziehungen. Frankfurt am Main: Campus, pp. 375-8.

Minkoff, D. C. (1997). Producing social capital: National social movements and civil society. American Behavioral Scientist, 40(5): 606-19.

Morel, N., Palier, B. and Palme, J. (2012). Towards a Social Investment Welfare State? Ideas, Policies and Challenges. Bristol: Policy Press. 
Morokvasic, M. (1999). La mobilité transnationale comme ressource: le cas des migrants de l'Europe de l'Est. Cultures et Conflits, 32: 105-22.

Münch, R. (2012). Inclusion and Exclusion in the Liberal Competition State: The Cult of the Individual. London: Routledge.

Mylonas, Y. (2012). Media and the economic crisis of the EU: The 'culturalization' of a systemic crisis and bild-zeitung's framing of Greece. tripleC, 10(2): 646-71.

Nikolova, M. (2014). Government funding of private voluntary organizations: Is there a crowding-out effect? Nonprofit and Voluntary Sector Quarterly, 44(3): 487-509.

Papathanassopoulos, S. (2015). European Media Views of the Greek Crisis. In S. Schifferes and R. Roberts (eds), The Media and the Financial Crises: Comparative and Historical Perspectives. New York: Routledge, pp. 103-18.

Parsons, T. (1951). The Social System. Glencoe, IL: Free Press.

Patulny, R. V. and Svendsen, G. L. H. (2007). Exploring the social capital grid: bonding, bridging, qualitative, quantitative. International Journal of Sociology and Social Policy, 27(1/2): 32-51.

Pensky, M. (2008). The End of Solidarity: Discourse Theory in Ethics and Politics. Albany: State University of New York Press.

Polletta, F. and Jasper, J. M. (2001). Collective identity and social movements. Annual Review of Sociology, 27: 283-305.

Putnam, R. D. (2000). Bowling Alone: The Collapse and Revival of American Community. New York: Simon \& Schuster.

Putnam, R. D., Feldstein, L. M. and Cohen, D. (2003). Better Together: Restoring the American Community. New York: Simon \& Schuster.

Rasmussen, D. M. (ed.) (1990). Universalism vs. Communitarianism: Contemporary Debates in Ethics. Cambridge, MA: MIT Press.

Raspotnik, A., Jacob, M. and Ventura, L. (2012). The Issue of Solidarity in the European Union. Discussion Paper for the TEPSA-Pre-Presidency Conference 14-15 June 2012. Cyprus: TEPSA.

Recchi, E. and Favell, A. (2009). Pioneers of European Integration: Citizenship and Mobility in the EU. Cheltenham, UK and Northampton, MA, USA: Edward Elgar Publishing.

Rehm, P., Hacker, J. S. and Schlesinger, M. (2012). Insecure alliances: Risk, inequality and support for the welfare state. American Political Science Review, 106(2): 386-406.

Reshaur, K. (1992). Concepts of solidarity in the political theory of Hannah Arendt. Canadian Journal of Political Science/Revue canadienne de science politique, 25(4): 723-36.

Ross, M. and Borgmann-Prebil, Y. (eds) (2010). Promoting Solidarity in the European Union. Oxford: Oxford University Press.

Schäfer, A. and Streeck, W. (eds) (2013). Politics in the Age of Austerity. Cambridge: Polity Press.

Scheepers, P. and Grotenhuis, M. T. (2005). Who cares for the poor in Europe? Micro and macro determinants for alleviating poverty in 15 European countries. European Sociological Review, 21(5): 453-65.

Scholz, S. J. (2008). Political Solidarity. University Park, PA: Penn State University Press.

Schroeder, D. A., Penner, L. A., Dovidio, J. F. and Piliavin, J. A. (1995). The Psychology of Helping and Altruism: Problems and Puzzles. New York: McGraw-Hill. 
Schulz-Forberg, H. and Stråth, B. (2010). Soft and Strong European Public Spheres. In R. Frank, H. Kaelble, M. F. Lévy and L. Passerini (eds), Building a European Public Sphere: From the 1950s to the Present. Brussels: Multiple Europes, pp. 55-76.

Skitka, L. J. and Tetlock, P. E. (1993). Providing public assistance: Cognitive and motivational processes underlying liberal and conservative policy preferences. Journal of Personality and Social Psychology, 65(6): 1205-23.

Smith, C. and Sorrell, K. (2014). On Social Solidarity. In V. Jeffries (ed.), The Palgrave Handbook on Altruism, Morality, and Social Solidarity: Formulating a Field of Study. New York: Palgrave Macmillan, pp. 219-48.

Smith, J. (2002). Bridging global divides? Strategic framing and solidarity in transnational social movement organizations. International Sociology, 17(4): 505-28.

Smith, J., Chatfield, C. and Pagnucco, R. (eds) (1997). Transnational Social Movements and Global Politics: Solidarity beyond the State. Syracuse, NY: Syracuse University Press.

Statham, P. and Trenz, H. J. (2013). The Politicization of Europe: Contesting the Constitution in the Mass Media. New York: Routledge.

Stegmueller, D., Scheepers, P., Roßteuscher, S. and de Jong, E. (2012). Support for redistribution in Western Europe: Assessing the role of religion. European Sociological Review, 28(4): 482-97.

Stjernø, S. (2012). Solidarity in Europe: The History of an Idea. Cambridge: Cambridge University Press.

Svallfors, S. (1997). Worlds of welfare and attitudes to redistribution: A comparison of eight western nations. European Journal of Sociology, 13(3): 283-304.

van Oorschot, W. (2000). Who should get what, and why? On deservingness criteria and the conditionality of solidarity among the public. Policy \& Politics, 28(1): $33-48$.

van Oorschot, W. (2006). Making the difference in social Europe: Deservingness perceptions among citizens of European welfare states. Journal of European Social Policy, 16(1): 23-42.

van Oorschot, W. and Arts, W. (2005). The social capital of European welfare states: The crowding out hypothesis revisited. Journal of European Social Policy, 15(1): 5-26.

van Oorschot, W., Arts, W. and Gelissen, J. (2006). Social capital in Europe: Measurement and social and regional distribution of a multifaceted phenomenon. Acta Sociologica, XLIX: 149-67.

van Setten, M., Scheepers, P. and Lubbers, M. (2017). Support for restrictive immigration policies in the European Union 2002-2013: The impact of economic strain and ethnic threat for vulnerable economic groups. European Societies, 19(4): 440-65.

Wessels, B. (2007). Discontent and European identity: Three types of Euroscepticism. Acta Politica, 42(2): 287-306.

Wilde, P. de, Michailidou, A. and Trenz, H. J. (2013). Contesting Europe: Exploring Euroscepticism in Online Media Coverage. Colchester: ECPR Press.

Wodak, R., Khosravinik, M. and Mral, B. (2013). Right-Wing Populism in Europe: Politics and Discourse. London: Bloomsbury Academic.

Zürn, M. and de Wilde, P. (2016). Debating globalization: Cosmopolitanism and communitarianism as political ideologies. Journal of Political Ideologies, 21(3): $280-301$. 